\title{
J Gleeson-White
}

Double Entry: How the Merchants of Venice Shaped the Modern World and How their Invention could Make or Break the Planet, Allen \& Unwin: Sydney, 2011, 294 + viii pp.: ISBN: 9781741757552

Reviewed by: Alan Sangster, Griffith University, Australia

This is a very interesting and easy to read book from which I gained a great deal of pleasure. The author should be commended on her courage and her success in absorbing and then retelling the history of a subject that those more equipped to do so have generally not done for the simple reason that the sum is greater than the parts finding evidence is one thing, putting it all together in a coherent and internally consistent manner, is another.

The Contents List is a challenging mixture of accounting history, economic history, and accounting - the art, the science, and the profession. The opening focus on the inability of accounting, as we know it, to present in financial statements items other than those that can be expressed in monetary terms is both surprising and refreshing. The call made later in the book for a reinvention or redesign of an accounting which embraces such factors as the impact upon the environment is well written and argued, and extremely timely. Professor Rob Gray's "elephant in the room" $(2010,2013)$ has rarely had such an outing in public, even if his writings and those of many others on the subject are strangely absent from this book.

It is a difficult enough task to understand sufficiently well the treatise on bookkeeping contained in Luca Pacioli's Summa Arithmetica of 1494, without attempting to also understand the activities and processes of accounting in the previous 200 and subsequent $500+$ years - a modernised translation of the treatise was sufficient to warrant a PhD (Cripps, 1995). This is not a minor task that Jane GleesonWhite set herself. In its fullness, it is nothing less than the work of an entire lifetime, and Jane Gleeson-White did it all in three years. Could this be possible? Today, with the freedom of the "library on your desktop" (Sangster, 1995: 3) finally realised, possibly, but it is still an enormous task requiring the reading of hundreds of articles, books, and websites. This was a challenge indeed and Jane Gleeson-White emerges from her travail with honour and achievement. Yet, speed is not the mother of all invention. Rather, it is the inevitable creator of shortcuts and assumptions arising from limited time to follow things through that are destined to leave questions only partially answered. Nevertheless, in this case, the flaws are not sufficient to devalue the whole. This is a very well-constructed book.

I found some chapters particularly interesting:

- The Preface is a superb, short, yet very informative introduction to the book.

- Chapter 7 ("Double entry and capitalism - chicken and egg?") which, while by no means covering the literature on this topic, nevertheless presents some worthy insights to the topic for those who have not encountered it previously. More from Basil Yamey would certainly not have gone amiss, as would the inclusion of material on capitalism and accounting in The Netherlands in the sixteenth century, where Funnell and Robertson (2011) suggest bookkeeping practice derived not from Pacioli but from German business practices.

- Chapter 8 ("John Maynard Keynes, double entry and the wealth of nations") opens 
up a debate much needed to support and understand the Conclusion to the book. The material is brief and well-written, however, I do find the tenuous link to double entry bookkeeping something of a stretch. I seriously doubt if John Maynard Keynes had, as is implied on p.179, any great interest in, or more than a passing knowledge of the principles of double entry bookkeeping, if that. He will, however, have understood how to construct economic financial models of the economy using the principles of algebra, upon which the duality of double entry is based. The marvel of balance in an accounting system based upon double entry is a mathematical one, nothing more and nothing less, and $\mathrm{Y}=\mathrm{C}+\mathrm{I}$ is an algebraic equation, as is the accountant's Capital = Assets - Liabilities. This wish of Jane Gleeson-White to brand everything under the umbrella of "double entry bookkeeping" is admirable, but, I would suggest, misplaced.

- Chapter 9 ("The rise and scandalous rise of a profession") is one of the highlights of the book. Some of the history recounted is incomplete and some of the statements made are misleading due to their inaccuracy, but the overall message of this chapter is strong and, I believe, appropriate. The author clearly believes that accounting scandals create more work for accountants, more demand for accounting services, and more jobs for accountants, and, in short, that accounting scandals are "good" for the accounting profession, and no one else. Accounting creates the image the decision makers wish it to create; accountants cannot agree on what is a "correct" interpretation of the data they have - and, much more. The manner in which the discussion towards the end of the chapter moves from accounting scandals to the $\$ 200$ Big Mac and then to a very brief discussion of the flaws of GDP is very well done and a very good lead-in to Chapter 10.

- Chapter 10 ("Gross Domestic Product and how accounting could make or break the planet") and the Epilogue chapter are thought provoking and a wonderful climax to this excellent book.

Among specific criticisms I have of the choice of content of the book, the "rules versus principles" distinction is introduced too briefly on pp.156-157, and the not very convincing link to the "is accounting a science?" debate is one of the low points of this book. The computerisation of accounting is barely mentioned (p.204): surely something ought to have been included concerning how auditors responded? And, surely more could have been made of the changing world of accounting arising from eBusiness and eCommerce, and, not least, the far higher profile today of forensic accounting. Furthermore, surely something ought to have been included on the beginnings of accounting standards in the US in the 1930s and the UK in the 1940s. In the history of the discipline, these were important steps and it is disappointing that Ms Gleeson-White seems to think that these initiatives originated in 1970 (p.206).

While these appear to be small points and not so much strong negatives as an indication of how coverage of topics could be enlarged in subsequent editions, it is fair to say that the book is not "all good". The first six chapters are a curate's egg of underresearched and, sometimes, misunderstood analysis, accompanied by wonderful clarity and exposition of a seriously complicated story: the history of double entry bookkeeping. I compiled a long list of inaccuracies - 41 of them - while reading through these 160 pages. One incorrect statement every four pages is an exceptionally high error ratio if a book is to be taken seriously, and that is before consideration is taken of the virtual absence of a number of topics, not least charge and discharge 
accounting and the manner in which it survived for hundreds of years after the emergence of double entry bookkeeping. Double entry had a serious rival and yet Ms Gleeson-White gives the impression that as soon as Pacioli's treatise was published in 1494 , everyone adopted double entry and that businesses thrived and prospered as a result; neither is the case.

As an accounting historian and specialist in Pacioli and the birth of double entry bookkeeping, I found the author's approach to citation exceedingly odd and unhelpful. In 1942, R. Emmett Taylor produced his wonderful biography of Luca Pacioli, No Royal Road. The dust jacket reveals that the typists who worked on his manuscript found it humorous and pre-publication reviewers commented upon his success in recreating the life of the times of Pacioli, but that book has one serious flaw noted by every historian who has ever used it as a source of information: you often cannot tell or identify which of Taylor's sources is related to which of his "facts". This was the style of academic writing evident in early Anglo-Saxon articles on accounting and accounting history (as seen for example, in the Accounting Review in the 1920s) but, by the 1940s, the style was no longer in vogue and was certainly not considered helpful to either serious researchers or students.

Jane Gleeson-White writes a good story and the story she weaves flows well but, in avoiding Taylor's unfortunate choice of referencing style, she has elected to adopt a strange mishmash of sources located at the end of the book. The entries in a section entitled "Notes" can be matched to their use in the text if you look for quoted phrases on the page indicated. These "notes" are followed by three lists of publications: in books, journals, and online, but they are not, in any instance, linked to the relevant text. This approach is inefficient and, at best, very unhelpful to any scholar. It must be of very limited use indeed to anyone else. Ms Gleeson-White's publisher has made a poor choice here. A footnote referencing style would have suited both audiences.

It would also help if sources are attributed whenever they ought to be rather than when the author feels they should be: I noted a number of instances where I knew the likely source of the text but could find no indication of it in the notes and references sections of the book. Accuracy in the references could also be improved. For example, the inclusion of material on p.162 attributed to Carnegie and Wolnizer in the Notes on p.265 is actually a quote from Sombart, something Ms Gleeson-White would know if she looked more carefully at the Carnegie and Wolnizer edited work and then dug further.

Nevertheless, despite its flaws, the book is the first primer to accounting history and its relevance to the modern world that I have ever seen. It is suitable for use as a core text for a one-semester or year-long university module/course on accounting history. I am currently teaching a postgraduate class in accounting history and would happily use this book as the core student background reading text on which all the articles I currently use are hung. In this sense, the flaws in this book are its strengths, offering opportunities for debate and investigation while maintaining an impressive aura of certainty for anyone not informed enough to spot the problems. For the benefit of those interested in identifying the errors and misconceptions I have found, these are presented in an Appendix to this review, along with a bibliography of the sources which I have used both here and in the Appendix.

Gleeson-White may be encouraged to go further in developing her understanding of accounting and accountants. Voices such as hers are desperately needed if we are to 
break the mould and create accounting that considers the world we live in as much as the enterprise for which it is being applied. The history of double entry bookkeeping tells us from where our present-day accounting practices came. Now, it is time to let the stasis of 700 years of practice evolve into something truly useful, something suited to the knowledge age in which we now live.

\section{Bibliography}

Antinori C (2000) Introduzione. In: Luca Pacioli De Divina Proportione. Roma: Istituto Poligrafico e Zecca Dello Stato.

Baldi B (1589) Fra Luca dal Borgo S. Sepolcro. Republished in: Boncompagni B (ed.) (1879) Bulletino di bibliographia e di storia delle scienze matematiche e fisiche. Volume XII, pp.421-427.

Bagni GT (2009) Luca Pacioli, the mathematics of his time and De viribus quantitatis. Forward accompanying Luca Pacioli's De Viribus Quantitatis. Petruzzi: Città di Castello, pp.21-28.

Bailey D (1992) The attempt to establish the Russian accounting profession 18751931. Accounting, Business and Financial History 2(1): 1-23.

Belloni G (1994) Nota Filologico-Linguistica. In: Luca Pacioli Trattato di Partita Doppia Venezia 1494. Venice: Albrizzi Editore, pp.35-44.

Brown NM (2010) The Abacus and the Cross: The Story of the Pope Who Brought the Light of Science to the Dark Ages. New York, NY: Basic Books, p.88.

Cangi D, Mattioni P, Novelli L, Massi G and Mercati C (2010) Da Euclide a Luca Pacioli: confronti linguistici e culturali. In: Martelli M (ed.) Pacioli Fra Arte e Geometria. Sansepolcro: Centro Studi "Mario Pancrazi", pp.57-67.

Ceci F, Fratini F, Marioli G, Pecchia M and Ricci G (2010) Luca Pacioli e la figura del mercante all'alba dell'età moderna con particolare riferimento a Venezia. In: Martelli M (ed.) Pacioli Fra Arte e Geometria. Sansepolcro: Centro Studi "Mario Pancrazi", pp.73-89.

Cripps JGA (1995) Particularis de computis et scripturis: 1494, Luca Pacioli; A contemporary interpretation. Seattle, WA: Pacioli Society.

Davis MD (1977) Piero della Francesca's mathematical treatises: the Trattato d'abaco and Libellus de quinque corporibus regularibus. Longo Editore: Ravenna.

De Roover R (1937) Aux origines d'une technique intellectuelle: La formation et l'expansion de la comptabilite a partie double. In: Annales d'Histoire économique et sociale 44-45: 171-193; 270-298.

De Roover R (1941) A Florentine firm of cloth manufacturers.

Speculum 16(1): 3-33.

De Roover R (1967) The scholastics, usury, and foreign exchange. The Business History Review 41(3): 257-271.

Funnell W and Robertson J (2011) Capitalist accounting in sixteenth century Holland: Hanseatic influences and the Sombart thesis. Accounting, Auditing \& Accountability Journal 24(5): 560-586.

Gray R (2010) A re-evaluation of social, environmental and sustainability accounting: An exploration of an emerging trans-disciplinary field? Sustainability Accounting, Management and Policy Journal 1(1): 11-32.

Gray R (2013) Sustainability and accounting education: The elephant in the classroom. Accounting Education: An International Journal 22 (forthcoming). 
Grendler PF (1985) The organization of primary and secondary education in the Italian Renaissance. The Catholic Historical Review 71(2): 185-205.

Grendler PF (1989) Schooling in Renaissance Italy: Literacy and Learning, 13001600. Baltimore: The Johns Hopkins University Press.

Grendler PF (2002) The Universities of the Italian Renaissance. Baltimore: The Johns Hopkins University Press.

Jouanique P (1996) Three medieval merchants: Francesco di Marco Datini, Jacques Coeur and Benedetto Cotrugli. Accounting, Business and Financial History 6(3): 261-275.

Lemarchand Y (1994) Double entry versus charge and discharge accounting in eighteenth-century France. Accounting, Business and Financial History 4(1): 119145.

Mackinnon N (1993) The portrait of Fra Luca Pacioli. The Mathematical Gazette 77(479): 130-219.

McClain DL (2008) Checkmate again for Leonardo? Chess book's diagrams are linked to artist. International Herald Tribune, 18 April. Available at: http://www.nytimes.com/2008/04/18/arts/18iht-leo.1.12127016.html

Marinoni A (1997) Introduction. In: Marinoni A (ed) Luca Pacioli's De Viribus Quantitatis. Milan: Ente Raccolta Vinciana.

Nakanishi A (1979) On the life of Luca Pacioli. The Accounting Historians Journal 6(2): 53-59.

Orlandi A (2011) The affirmation of double-entry bookkeeping in the business accounts of Tuscan merchants in the Late Middle Ages. Presentation at The International Conference of Accounting Theory and History "View from the Past into the Future", St Petersburg, Russia, 10-11 February.

Pacioli L (1494) Summa de Arithmetica Geometria Proportioni et Proportionalita. Venice: Paganino de' Paganini.

Pacioli L (c.1500) De Ludu Scacchorum. Unpublished manuscript (facsimile published in 2007 by Aboca Museum, Sansepolcro).

Pacioli L (1509) De Divina Proportione. Venice: Paganino de' Paganini.

Peragallo E (1956) Origin of the trial balance. The Accounting Review 31(3): 389-394.

Picutti E (1989) Sui plagi matematici di frate Luca Pacioli. Le Scienze 246: 72-79.

Sangster A (1995) World Wide Web - what can it do for accounting education. Active Learning 1(2): 3-8.

Sangster A (2007) The printing of Pacioli's Summa in 1494: How many copies were printed. The Accounting Historians Journal 34(1): 125-146.

Sangster A (2011) Luca Pacioli, school teacher and university professor. In: HernándezEsteve E and Martelli M (eds) Before and After Luca Pacioli, Proceedings of ATTI II Incontro Internazionale, Sansepolcro-Perugia-Firenze, Italy, 17-19 June 2011. Sansepolcro: Aboca Edizioni, pp.457-472.

Sokolov YV and Sokolov VY (2011) Pacioli's ideas in Russian accounting history. In: Hernández-Esteve E and Martelli M (eds) Before and After Luca Pacioli, Proceedings of ATTI II Incontro Internazionale, Sansepolcro-Perugia-Firenze, Italy, 17-19 June 2011. Sansepolcro: Aboca Edizioni. Sansepolcro: Aboca Edizioni, pp. 787-816.

Stevelinck E (1986) The many faces of Luca Pacioli: Iconographic research over thirty years. The Accounting 
Historians Journal 13(2): 2-18.

Tagliente G (1525) Considerando ... la presente opereta per quelli che hano debisogno accio che sapi no tener ordinata mente el detto conto del suo libro ugnolo .... Venice: no publisher.

Taylor RE (1942) No Royal Road. New York: Arno Press.

Ulivi E (2009) Nuovi documenti su Luca Pacioli. In: Giusti E and Martelli M (eds) Pacioli 500 Anni Dopo. Sansepolcro: Centro Studi "Mario Pancrazi”, pp.19-58.

Yamey BS (1974) Luca Pacioli's scuola perfetta: A bibliographical puzzle. GutenbergJahrbuch: 110-116.

\section{Appendix}

\section{Inaccuracies}

1. Contrary to the statement on p.7, a great deal has been written about Luca Pacioli - well over 100 scholarly articles - undeniably more than have been written about any other individual in the entire history of accounting.

2. Contrary to the claim that the Datini books were in double entry from 1390 onwards (pp.23-24), Datini was using double entry in Pisa and Florence from 1386 (De Roover, 1937: 274-275; Orlandi, 2011).

3. The statement (p.26) that Datini kept his accounts using Roman numerals is, perhaps, incomplete. As can be seen from the actual records held in Prata, in 1383 Datini was using both Roman numerals and Hindu-Arabic numerals in his account books. It was the numerals in the third column, the "money column" that were in Roman numerals, hence it can be argued that the accounts were indeed kept using Roman numerals. However, in the first column can be seen examples where the same number is presented, but in Hindu-Arabic numerals.

4. "El modo de vinegia or alla viniziana: the Venetian method" (p.27) was more to do with the bilateral account form (where the debit and credit of each account appear opposite each other on the same side of a sheet of paper) than with the rest of Pacioli's description. That form of account presentation was in use in Florence around the end of the fourteenth century and described at that time as "alla veneziana". This is one of the reasons that it is considered that the bilateral form originated in Venice (De Roover, 1937: 181), even though the first confirmed example of its use in Venice that we have dates from 1430.

5. Pacioli was born between 20 June 1446 and 19 June 1447, not in 1445 (p.30). The record of his death on 19 June 1517 states that he was 70 years old (Nakanishi, 1979: 54).

6. It was not, as stated on p.39, Robert of Chester who introduced Europeans to the Hindu-Arabic numerals (in his 1145 translation into Latin of the algebra of AlKhwārizmī), but Gerbert d'Aurillac, a French scholar, teacher, and Pope (Sylvester II) who did so in the last quarter of the tenth century.

7. The use of the term, "published" to describe Fibonacci's Liber Abaci of 1202 is, perhaps, misleading for a modern audience who associate the term with printing (p.40). Liber Abaci was a manuscript book that was copied and used in abbreviated form, translated from its original Latin into the vernacular by many of the teachers of abbaco in Northern Italy. 
8. Prior to the emergence of the abbaco schools, the dominant school type in Northern Italy was not the Latin-based monastery schools (p.40), but the Latinbased independent Grammar schools (Grendler, 1985).

9. Girls were not "excluded" from formal education (p.41), though few attended school in the modern sense (Grendler, 1985, 1989).

10. Pacioli, the very young orphan living with a merchant in Sansepolcro, was not "taught old medieval scholasticism ... as well as the new Florentine humanism" (pp.43-44) - the humanist schools did not teach the scholastic curriculum; they taught the humanist curriculum (Grendler, 1985). Plus, his handwriting was in the style of mercantile script, which he would have learnt either at school, from a tutor or, more likely, from his guardian. It is unlikely that he would have been encouraged to use mercantile script in a scholastic grammar school or a church school. Plus, Pacioli went to Venice to act as guardian and taught the sons of Rompiasi when he was around 16 or 17 years old. They were the sons of a merchant. He taught them abbaco. To teach it, he would have had to have previously learnt it and it was learnt in abbaco schools which did not teach either medieval scholasticism or Florentine humanism.

11. Pacioli did not "live through the early decades of the morphing of Italian mathematics from medieval Roman to a fusion of Hindu-Arabic and Greek" (p.44). That fusion started with twelfth-century Latin translations of al-Khwārizmī's book on algebra, and continued in 1202 with Fibonacci's Liber Abaci. It was not a movement that started in the mid-fifteenth century.

12. Piero della Francesca did not just "supposedly" include Pacioli in one of his paintings (p.47), he included him in two (Stevelinck, 1986).

13. We do not know what Pacioli's "primary" duty was in the Rompiasi household (p.57); nor is there any evidence that he was "teaching ... bookkeeping" there or anywhere else, at any time in his life.

14. The vagueness - "40 years later" (p.58) - concerning when Pacioli was teaching in Venice (Bagni, 2009: 21) at the Scuola di Rialto (Ceci et al., 2010: 78) is unnecessary; it was 1508 and not 1504 or 1510, which are the possible dates that seem to be implied in the text.

15. There is no evidence that Pacioli "died a wealthy man" (p.62). Quite the opposite. It is likely he died relatively poor, following the apparent theft of his possessions in 1512 (Taylor, 942: 374-375). Had he died "wealthy", his desire for a tomb (Taylor, 1943: 372) would have been realized. It was not.

16. The book he started in Perugia in 1477 was not his Summa Arithmetica (p.62). It was his Tractatus Mathematicus ad Discipulos Perusinos (p.63).

17. We know very little about what Pacioli was doing between 1480 and 1486 . It is believed that between mid-1480 and mid-1484 he obtained his degree in theology: on September 24, 1484 he was mentioned as having the title "Magister Professor" (Ulivi, 2009: 35), not 1486 (p.64).

18. In 1486, although Pacioli was appointed to teach at Perugia, it was to teach abbaco. Abbaco was not taught in universities (Grendler, 1989: footnote 40, 419-420). All of Pacioli's teaching appointments in Perugia appear to have been at that level (Sangster, 2011). If so, he would never have held a chair in mathematics at that 
university though it has been stated by a number of writers (including myself) that he did (p.65).

19. Pacioli's contract in Perugia is believed to have expired in April 1488. He did not then return to Sansepolcro (p.65). After April 1488, he went to Rome and obtained a public lectureship (Baldi, 1589, c. 181r) at the university (Grendler, 2002: 59-60; Taylor, 1942: 161). His next teaching appointment was in Naples (Antinori, 2000: 13) where he was appointed as a public lecturer at the university, probably for some time during the period between July 1489 and October 1490.

20. Had he returned to Sansepolcro in 1488 as suggested (p.65), it would certainly not have been "for the first time since he had left it [to first go to Venice]". He was, for example, in Sansepolcro in February 1471, August 1472, and August 1473 (Ulivi, 2009).

21. Although it has been suggested that Pacioli was told to stop teaching the secular youth of Sansepolcro in 1491 (p.65), the instruction from his superiors in 1491 told him to close the secular school in Sansepolcro.

22. In 1494, Pacioli did not become the first author of a printed book on algebra (p.67). The first printed book to contain algebra was published in 1482: Euclides, Elementa Geometriae, printed in Venice by the publisher, Erhard Ratdolt (which is referred to on p.68).

23. The language of Pacioli's Summa Arithmetica is now recognised as being the language of the markets of northern Italy (Belloni, 1994; Marinoni, 1997) - the language which the merchants for whom it was written would need to have used in their work. Had it been written mainly in the Florentine dialect (p.73), it would have been applauded for the language in which it was written, not derided for its hybrid version of the vernacular (Cangi et al., 2010: 67).

24. There are estimated to be 162 extant copies of Summa Arithmetica (Sangster, 2007: 140), not 135 (p.74). In addition, one copy of the 1523 printing of Volume 1 was offered for sale in London in 2006 for $£ 18,500$, indicating that the two volumes were not always bound together into one book (p.74).

25. Pacioli did not simply translate Fibonacci's Liber Abaci. He used multiple sources for Summa Arithmetica. In addition, there is no reason to suggest that Liber Abaci was in need of restoration (presumably in the sense of reintroduction) for the benefit of European mathematics (p.75). It was the source for much that was written about mathematics by the abachists (the abbaco school teachers) at that time. In Summa Arithmetica, Pacioli acknowledged the debt all mathematicians owed to Fibonacci and took the mathematics that had been presented by Fibonacci and many others and included it in the vernacular in a printed book, with his own exposition and solutions. It was the printing of his book that brought this mathematics to the attention of Europe. He did not "restore" mathematics, rather, he developed and extended the existing state of mathematics in Western Europe.

26. Much of Volume 2 of Summa Arithmetica, from the beginning to folio 59v (118 of its 151 pages), is a direct transcription of the first 241 folios of the Praticha di geometria of Benedetto de Firenze (Picutti, 1989: 76). Thus most of this volume was sourced elsewhere than is indicated on p.75. Eleven of the remaining pages in that volume are, however, essentially identical to material in Piero della Francesca's Trattato d'Abaco (Davis, 1977). 
27. Summa Arithmetica was by no means "one of the earliest books to be printed on the Guttenberg Press" (p.77). This is a common misunderstanding. By 1501, there were over 1,000 printing shops in Europe and at least 150 in Venice; and it has been suggested that by 150135,000 different titles had been printed, representing a total of 20 million printed books. It has also been estimated that as many as 5,000 titles may have been printed in Venice before 1501 (see, Sangster, 2007). The fact that Summa Arithmetica was printed seven years before 1501 does not make it one of the earliest books to be printed in the 40-year period from 1454 to 1494.

28. Whether or not there was ever a printing of a book called La Scuola Perfetta dei mercanti is not clear. We have just one eye-witness from the nineteenth century (Yamey, 1974). While the book may have been printed, it is misleading to state this as if it were a confirmed fact (p.78).

29. De Viribus Quantitatis was not published for many years, but it has been published in print, for example, in Marinoni (1997) and, most recently, in facsimile by the Aboca Museum of Sansepolcro in 2009 (p.83).

30. Pacioli worked for the University of Pisa in Florence, not for the University of Florence, and he worked there from 1500, not 1499 (p.84).

31. There was a suggestion made in 2008 that Leonardo Da Vinci did the illustrations for Pacioli's book of chess problems, De Ludu Scachorum (c. 1500) (p.87) but, even to the untrained eye, this must seem fanciful. As one expert on Leonardo stated concerning this possibility: "There is not an earthly chance of them being by Leonardo ... [t] he silly season on Leo never closes" (McClain, 2008).

32. Pacioli's lasting fame is not confined to accounting (p.88). His work is studied as much by mathematical historians as by accounting historians, possibly even more so; and he is famed for the calligraphy of his design of an alphabet published in $D e$ Divina Proportione in 1509.

33. No one knows who first devised the system of two equal and opposite entries in the ledger for every transaction but, from what we know, the first place the system of double entry bookkeeping was used was in Salon, France, in or before 1299. To suggest that the Venetians invented double entry in the face of all the evidence is fanciful (p.100). What Venetians probably invented was the bilateral account, where the credit entries in an account are made on the right-hand-side of the same page as the debits, which are made on the left-hand-side (De Roover, 1937).

34. On p.107, there is an error in the example concerning a purchase of 20 pieces of white cloth which was introduced on p.105. On p.107, the text mentions ten pieces at $£ 12$ while the calculations produce an amount for the purchase (which is correct) of $€ 240$.

35. Despite mentioning that the ledger closing process would enable a Trial Balance to be produced, the author joins illustrious authors of the past (see, Peragallo, 1956: 390, 392-393) and confuses Pacioli's Summa Summarium with the trial balance, describing the former not the latter (p.111). The process to be followed in order to prepare a trial balance, which Pacioli summarises very briefly in Chapter 36 of his treatise, is not included in Ms Gleeson-White's book.

36. The author is confused by Pacioli's instructions for closing the books (p.112). In 
Chapter 34 of his treatise, Pacioli explains very carefully how to transfer the balances of the asset and liability and capital accounts from the current ledger to the new ledger. The list of types of accounts which starts on the fourth line of p.112 is the same as that given by Pacioli. However, these account balances are not transferred to Profit and Loss, which is what Ms Gleeson-White states. Pacioli, in fact, says that balances on expense accounts (i.e. accounts other than asset, liability, and capital accounts) should not be transferred to the new ledger, but should, instead, be transferred to the "favour and damage account", or "increase and deficit", or "profit and damage account" - i.e. the profit and loss account. As Ms Gleeson-White then correctly states, once the balance on this account is known, it is closed by transferring the balance to the capital account.

37. Ratdolt discovered how to place complex designs in a printed book (Mackinnon, 1993: 135) but this had very little to do with the demise of Roman numerals (p.116) - how could it? Nor could this discovery have contributed to the demise of Latin as the universal language of Europe (p.116). Latin was surely no more difficult to print than Italian. Printing in general contributed to the demise of Latin as it facilitated the spread of usage of the everyday spoken language.

38. Many books on bookkeeping between 1500 and 1800 were based directly or indirectly upon Pacioli's treatise (p.131) but, not all - see, for example, Tagliente's (1525) treatise on single entry for merchants and artisans. This goes to the root of an apparent blind spot of the author: while double entry bookkeeping was used throughout much of Europe in that period, it was not used by anything like the majority of businesses until the rise of the joint stock companies in the nineteenth century - see, for example, Lemarchand's (1994) excellent article on eighteenth century French accounting. Some governments tried to impose double entry, but all failed to extend its use beyond those enterprises over which they had some control. Otherwise, double entry was adopted when the business owners saw an advantage in its use or, presumably, where the person keeping the books preferred the method over single entry accounting. The impression in Ms Gleeson-White's text is that double entry bookkeeping as described by Pacioli was widely adopted after the publication of Pacioli's treatise in 1494. It was not.

39. In 1772 Wedgwood was probably one of the first businesses to use double entry bookkeeping and involve its use in the analysis of costs (p.138). However, it was not one of the "early" firms to do so. As De Roover (1941: 28) points out, this was something that the Medici had been trying to do over 200 years earlier, in the first half of the sixteenth century:

The [double entry] bookkeeping system of the Medici Florentine cloth manufacturing partnerships was entirely adequate for their purpose and fitted perfectly their organization. It provided the means which the management needed to control the flow of material as well as the movement of funds. It was not yet a cost-finding system, but it came very close to being one. The account books give enough indication to permit one to assume that the Medici had a good knowledge of their approximate cost and used this information in pricing their finished cloth.

40. Depreciation was not something that first arose following the emergence of corporations in the nineteenth century (p.148). By then, it had been in use for five centuries, including in the books of the fifteenth-century Medici cloth manufacturing partnerships and the fourteenthcentury Datini partnerships (De Roover, 1937: 275; 1941). 
41. Russia was hardly a nation of bookkeepers in 1900 (pp.153-154). Although it has been used in this context by, for example, Bailey (1992), use of the term "bookkeeper" when referring to accountants in late 19th century Russia is misleading and needs to be interpreted without the demeaning perjorative in which the term is viewed today. These Russian "bookkeepers" were every bit as much "accountants" as those recognised as such elsewhere. Double entry bookkeeping was in use in Russia in the eighteenth century and public associations of accountants appeared in Russia late in the nineteenth century with their own professional journals, such as Accounting (Schetovodstvo) and Practical Life (Prakticheskaya zhizn) from 1888 and 1889, respectively. Pacioli and his treatise were discussed in a publication in 1809 by Karl Ivanovich Arnold, in the same year by Ivan Akhmatov, and in the following year by the President of the Russian Academy of Arts, AN Ilenin. Pacioli was held in very high regard in Russia and Russian accountants celebrated the 400th anniversary of the publication of Pacioli's treatise in December 1894 with the first translation of the treatise into Russian (by Eduard Grigorievich Valdenberg), speeches, and a dinner (Sokolov and Sokolov, 2011).

42. The book touches on usury and presents the views of James Aho, but his perspective needs to be balanced with others, such as those expressed by Raymond De Roover (1967) and Pierre Jouanique (1996) who do not see the issue as having been of such import in Medieval and Renaissance Europe as Professor Aho suggests. In addition, and more critically, the suggestion that usury is no longer relevant (to accounting) (p.173) wrongly ignores the position faced by Muslim accountants, as a routine search of the Internet will reveal.

43. Accounting did not first awake to the need for some additional regulation in the 1970s, and the Americans were the first to act, not the British (p.206).

44. "True and fair" is very much a UK invention, being enshrined in the 1947 UK Companies Act at the behest of the ICAEW, long before the establishment of the Accounting Standards Steering Committee by the ICAEW in 1970. It is not a concept that the US FASB has been involved in codifying (p.206).

45. To suggest that more regulation and further standardisation of the accounting profession from 1970 onwards "did nothing to avert or even diminish accountingrelated corporate scandals" (p.207) is simply indefensible. There is no means of knowing whether or not increasing regulation and further standardisation had a neutral effect, but it seems highly unlikely that, if we had a parallel universe devoid of such measures, it would not have experienced more scandals of this type than ours.

46. It will not be only "in the long-term that the SEC will accept IFRS standards" (p.214), it already does, and has done so without requirement of any reconciliation with US GAAP since March 2008. However, this does not apply as yet, to US corporations, which is the point the author ought to have made.

47. Accounting scandals have been occurring since the South Sea Company and Mississippi Company scandals of 1720 . They did not start to occur in the 1860 s (p.215). 